\title{
Effects of Controlled Irrigation and Drainage on Nitrogen and Phosphorus Concentrations in Paddy Water
}

\author{
Shi-kai Gao, Shuang-en Yu, Guang-cheng Shao, Dong-li She, Mei Wang, \\ Rong Guo, Rui-zhe Cao, Shao-feng Yan, and Ji-hui Ding \\ Key Laboratory of Efficient Irrigation-Drainage and Agricultural Soil-Water Environment in Southern China, Ministry of Education, \\ College of Water Conservancy and Hydropower Engineering, Hohai University, Nanjing 210098, China
}

Correspondence should be addressed to Shi-kai Gao; igaoshikai@163.com and Shuang-en Yu; seyu@hhu.edu.cn

Received 14 March 2016; Revised 13 May 2016; Accepted 16 May 2016

Academic Editor: Jun Wu

Copyright (C) 2016 Shi-kai Gao et al. This is an open access article distributed under the Creative Commons Attribution License, which permits unrestricted use, distribution, and reproduction in any medium, provided the original work is properly cited.

Controlled irrigation and drainage (CID) has received attention for improving water quality. Under CID condition, water stress is frequently experienced in two contexts: first drought and then flooding (FDTF) and first flooding and then drought (FFTD). This study aimed to investigate the effects of FDTF and FFTD on nitrogen (N) and phosphorus (P) dynamics in paddy water at different growth stages. The effects of water stress on the migration and transformation of $\mathrm{N}$ and $\mathrm{P}$ were also investigated. Results showed that $\mathrm{CID}$ can decrease $\mathrm{N}$ and $\mathrm{P}$ concentrations in surface water. $\mathrm{NH}_{4}{ }^{+}-\mathrm{N}$ was the major form of $\mathrm{N}$ in surface drainage and percolation water. Mean total phosphorus (TP), $\mathrm{NH}_{4}{ }^{+}-\mathrm{N}$, and $\mathrm{NO}_{3}{ }^{-}-\mathrm{N}$ concentrations were significantly higher than in FFTD during the growth stage. Mean $\mathrm{NH}_{4}{ }^{+}-\mathrm{N}, \mathrm{NO}_{3}{ }^{-}-\mathrm{N}$, and $\mathrm{TP}$ concentrations were significantly higher in percolation water under flooding stress than those under drought stress at growth stage, except for mean TP concentrations at milky stage (stage IV). Meanwhile, flooding can sharply increase the $\mathrm{NH}_{4}{ }^{+}-\mathrm{N}, \mathrm{NO}_{3}{ }^{-}-\mathrm{N}$, and TP concentrations in percolation water after drought. Thus, without CID, the considerably high $\mathrm{NH}_{4}{ }^{-}-\mathrm{N}, \mathrm{NO}_{3}^{-}-\mathrm{N}$, and TP concentrations via runoff and leaching can be responsible for the eutrophication of water bodies in the vicinity of paddy fields during the rice growing season when water stress transforms from drought into flooding.

\section{Introduction}

Agricultural nonpoint source pollution is a major environmental issue in many countries with intensive farming systems $[1,2]$. Nitrogen $(\mathrm{N})$ and phosphorus $(\mathrm{P})$ loads from unmanaged agricultural nonpoint sources [2], such as runoff and leaching from paddy fields, have been associated with water body eutrophication of many lakes and streams [3, 4]. Paddy rice is one of the most important food crops in Southern China [5-7]. The utilization of $\mathrm{N}$ is relatively low in irrigated rice because of rapid $\mathrm{N}$ losses through surface runoff, denitrification, leaching, and ammonia volatilization [8]. Moreover, irrational drainage shortens the residence time of water and accelerates the $\mathrm{N}$ and $\mathrm{P}$ losses [9], resulting in an increase in $\mathrm{N}$ losses from the paddy fields to adjacent waters. However, $\mathrm{P}$ is relatively stable in soils and thus runoff and leaching are the major routes of excessive P losses [10].
Previous research showed that the total drainage outflow was a primary factor in $\mathrm{N}$ and $\mathrm{P}$ losses in paddy fields [11]. Attempts to reduce the nutrient losses in drainage water have led to the promotion of controlled drainage (CD), which has shown the best potential for improving water quality [12-15]. Large amounts of water outputs saved can be obtained in $\mathrm{CD}$ systems $[11,16]$. In addition, $\mathrm{N}$ and $\mathrm{P}$ concentrations are reduced through crop uptake, nitrification, denitrification, and sediment deposition [14]. However, water conservation has become a basic national policy in China given the shortage of water resources $[17,18]$. The most widely promoted water-saving technology for rice so far is alternate wetting and drying (AWD) [19]. The adoption of water-saving technologies could alter $\mathrm{N}$ and $\mathrm{P}$ dynamics and lower nutrient losses $[19,20]$. Peng et al. showed that $\mathrm{N}$ and $\mathrm{P}$ losses were reduced with AWD compared to conventional irrigation under the same $\mathrm{N}$ management [18]. 
TABLE 1: Controlled thresholds in different stages for controlled irrigation and drainage (CID) in the year 2015.

\begin{tabular}{lccccc}
\hline Treatments & $\begin{array}{c}\text { Tillering stage } \\
\text { (stage I) }\end{array}$ & $\begin{array}{c}\text { Jointing-booting } \\
\text { stage (stage II) }\end{array}$ & $\begin{array}{c}\text { Panicle initiation } \\
\text { stage (stage III) }\end{array}$ & $\begin{array}{c}\text { Milky stage (stage } \\
\text { IV) }\end{array}$ & $\begin{array}{c}\text { Period of water } \\
\text { control }\end{array}$ \\
\hline \multirow{3}{*}{ FDTF } & $\mathbf{- 5 0 0 \sim 2 0 0}$ & $-200 \sim 50 \sim 200$ & $-200 \sim 50 \sim 200$ & $-200 \sim 50 \sim 200$ & Jul. 3-Jul. 12 \\
& $-200 \sim 20 \sim 100$ & $-\mathbf{5 0 0 \sim 2 5 0}$ & $-200 \sim 50 \sim 200$ & $-200 \sim 50 \sim 200$ & Jul. 29-Aug. 6 \\
& $-200 \sim 20 \sim 100$ & $-200 \sim 50 \sim 200$ & $-\mathbf{5 0 0 \sim 2 5 0}$ & $-200 \sim 50 \sim 200$ & Aug. 24-Sep. 2 \\
& $-200 \sim 20 \sim 100$ & $-200 \sim 50 \sim 200$ & $-200 \sim 50 \sim 200$ & $-\mathbf{5 0 0 \sim 2 5 0}$ & Sep. 16-Sep. 25 \\
FFTD & $\mathbf{2 0 0 \sim - 5 0 0}$ & $-200 \sim 50 \sim 200$ & $-200 \sim 50 \sim 200$ & $-200 \sim 50 \sim 200$ & Jul. 3-Jul. 14 \\
& $-200 \sim 20 \sim 100$ & $\mathbf{2 5 0}-\mathbf{5 0 0}$ & $-200 \sim 50 \sim 200$ & $-200 \sim 50 \sim 200$ & Jul. 29-Aug. 7 \\
& $-200 \sim 20 \sim 100$ & $-200 \sim 50 \sim 200$ & $\mathbf{2 5 0}-\mathbf{5 0 0}$ & $-200 \sim 50 \sim 200$ & Aug. 24-Sep. 4 \\
& $-200 \sim 20 \sim 100$ & $-200 \sim 50 \sim 200$ & $-200 \sim 50 \sim 200$ & $\mathbf{2 5 0}-\mathbf{5 0 0}$ & Sep. 16-Sep. 28 \\
\hline
\end{tabular}

Note: $-I \mathrm{~mm} \sim J \sim K \mathrm{~mm}$ denotes that water depth was kept between $-I \mathrm{~mm}$ and $J \mathrm{~mm}$ at four stages of rice paddies at normal time; the maximum water height after rainfall for the control is $K \mathrm{~mm}$. When water level lowered to $-I \mathrm{~mm}$, irrigation water is added until water level reached $J \mathrm{~mm}$. $-H \mathrm{~mm} \sim L \mathrm{~mm}$ or $L \mathrm{~mm} \sim-H \mathrm{~mm}$ indicates the controlled thresholds of water level in different stages. The allowable variation of fixed water level was $\pm 5 \mathrm{~mm}$ during the period of implementation; $2 \mathrm{~mm}$ water leakage per day was adopted when surface water existed. FDTF indicates first drought and then flooding; FFTD indicates first flooding and then drought.

Although many studies have investigated migration and transformation of $\mathrm{N}$ and $\mathrm{P}$ in paddy fields individually under AWD and CD $[1,18,19]$, only a few studies have focused on the conjunct influences of $\mathrm{CD}$ and AWD on the migration and transformation of $\mathrm{N}$ and $\mathrm{P}$. Controlled irrigation and drainage (CID) aims to combine the advantages of $\mathrm{CD}$ and AWD. The basic feature of CID is to maintain a high depth of water so that the drainage water is reduced during rainy days and used when a certain threshold water table is reached (a certain degree of drought stress is produced when soil moisture content is lower than the saturated moisture content and even field capacity). Thus, paddy fields may experience frequent episodes of alternate drought and flooding to various degrees under CID condition. The desirable $\mathrm{N}$ and $\mathrm{P}$ changes and losses may be different from those under drought or flooding stress alone. CID practice tends to result in dramatic changes in the soil physical environment, including the aerobic and anaerobic transitions [21]. Under CID condition, water stress may be frequently experienced in two contexts: first drought and then flooding (FDTF) and first flooding and then drought (FFTD). The current study attempts to reveal the $\mathrm{N}$ and $\mathrm{P}$ dynamics in surface and percolation water from rice paddies under FDTF and FFTD conditions, as well as determine the effects of water stress on the migration and transformation of $\mathrm{N}$ and $\mathrm{P}$.

\section{Materials and Methods}

2.1. Experimental Site and Soil Properties. The experiments were conducted in specially designed experimental tanks at the Key Laboratory of Efficient Irrigation-Drainage and Agricultural Soil-Water Environment in Southern China, Ministry of Education (Nanjing, latitude $31^{\circ} 57^{\prime} \mathrm{N}$, longitude $118^{\circ} 50^{\prime} \mathrm{E}, 144 \mathrm{~m}$ above sea level), during the rice growing season of 2015 (i.e., May to October). The experimental site experiences a subtropical, humid climate with an annual mean temperature of $15.4^{\circ} \mathrm{C}$. The mean annual precipitation at Nanjing City (located $20 \mathrm{~km}$ northeast of the experimental site) is $1047 \mathrm{~mm}$, with mean annual evaporation of $900 \mathrm{~mm}$.
The air temperature, wind speed and direction, relative humidity, total solar radiation, and photosynthesis active radiation were measured at the experimental site using an automated weather station. Precipitation was measured by a tipping bucket rain gauge. All meteorological parameters were stored in a data logger and downloaded weekly via a computer. The frost-free period lasts for 220 days per year. The soil in the area is a typical permeable paddy soil, formed on loess deposits, with loamy clay. A total of 25 fixed tanks plots were prepared (length $\times$ width $\times$ depth $=2.5 \mathrm{~m} \times 2 \mathrm{~m} \times$ $2 \mathrm{~m})$. The irrigation system is an automatic irrigation system controlled by the host electromagnetic valve. The soil $(0-$ $30 \mathrm{~cm}$ ) in tanks with pH of 6.97 contained $2.19 \%$ of soil organic matter, $0.91 \mathrm{~g} / \mathrm{kg}$ of total nitrogen, $27.65 \mathrm{mg} / \mathrm{kg}$ of available nitrogen, $0.32 \mathrm{~g} / \mathrm{kg}$ of total phosphorus (TP), and $12.5 \mathrm{mg} / \mathrm{kg}$ of available phosphorus.

2.2. Plant Material and Cultivated Practices. Nangeng 9108, a high-yielding rice variety currently used in local production, was grown in the paddy tanks. Seedlings were raised in a seedbed on May 13, 2015, and then transplanted on June 16, 2015 , at a hill spacing of $0.2 \mathrm{~m} \times 0.14 \mathrm{~m}$, with three seedlings per hill. A week before transplanting, the experimental plots were dry-ploughed and harrowed. The soil was soaked a day before transplanting and then flooded for about a week with a $2-3 \mathrm{~cm}$ water layer to promote good crop establishment. The basal fertilizer was the compound fertilizer $\left(\mathrm{N}: \mathrm{P}_{2} \mathrm{O}_{5}: \mathrm{K}_{2} \mathrm{O}\right.$, $15: 15: 15)$ and $900 \mathrm{~kg} / \mathrm{ha}$ was applied on June 13,2015 . The tillering fertilizer was urea (with a nitrogen content of $46.4 \%$ ), and $100 \mathrm{~kg} / \mathrm{ha}$ was applied on June 28,2015 . The panicle fertilizer was also urea (with a nitrogen content of 46.4\%), and $50 \mathrm{~kg} / \mathrm{ha}$ was applied on August 18, 2015. The weed was controlled manually and pesticides were applied occasionally.

2.3. Experimental Design. Eight CID treatments were designed for the experiment (Table 1). According to the characteristics of rice growth stage, we chose tillering stage (stage I), jointing and booting stage (stage II), heading and flowering stage (stage III), and milky stage (stage IV) for 
TABLE 2: Mean TP, $\mathrm{NH}_{4}{ }^{+}-\mathrm{N}$, and $\mathrm{NO}_{3}{ }^{-}-\mathrm{N}$ concentrations in surface water at different stages.

\begin{tabular}{lccccc}
\hline $\begin{array}{l}\text { Form of N and } \mathrm{P} \\
\left(\mathrm{mg} \cdot \mathrm{L}^{-1}\right)\end{array}$ & Treatments & $\begin{array}{c}\text { Tillering stage } \\
(\text { stage I) }\end{array}$ & $\begin{array}{c}\text { Jointing-booting } \\
\text { stage (stage II) }\end{array}$ & $\begin{array}{c}\text { Panicle initiation } \\
\text { stage (stage III) }\end{array}$ & $\begin{array}{c}\text { Milky stage (stage } \\
\text { IV) }\end{array}$ \\
\hline \multirow{2}{*}{$\mathrm{NH}_{4}{ }^{+}-\mathrm{N}$} & FFTD & $6.20^{\mathrm{a}}$ & $2.59^{\mathrm{a}}$ & $4.82^{\mathrm{a}}$ & $1.53^{\mathrm{a}}$ \\
& FDTF & $7.27^{\mathrm{b}}$ & $3.31^{\mathrm{b}}$ & $5.62^{\mathrm{b}}$ & $1.93^{\mathrm{b}}$ \\
\hline \multirow{2}{*}{$\mathrm{NO}_{3}{ }^{-}-\mathrm{N}$} & FFTD & $2.01^{\mathrm{a}}$ & $1.31^{\mathrm{a}}$ & $2.04^{\mathrm{a}}$ & $0.88^{\mathrm{a}}$ \\
& FDTF & $3.14^{\mathrm{b}}$ & $2.07^{\mathrm{b}}$ & $2.63^{\mathrm{b}}$ & $1.23^{\mathrm{b}}$ \\
\hline \multirow{2}{*}{$\mathrm{TP}$} & FFTD & $0.16^{\mathrm{a}}$ & $0.10^{\mathrm{a}}$ & $0.06^{\mathrm{a}}$ & $0.03^{\mathrm{a}}$ \\
& FDTF & $0.25^{\mathrm{b}}$ & $0.16^{\mathrm{b}}$ & $0.96^{\mathrm{b}}$ & $0.47^{\mathrm{b}}$ \\
\hline
\end{tabular}

Note: mean values in the same row followed by the same letter show nonsignificant difference. FDTF indicates first drought and then flooding; FFTD indicates first flooding and then drought.

the experiments under different irrigation and drainage conditions. Treatments were set up in the paddy tanks with closed bottoms; each treatment had three replicates. For the FDTF treatments, rice experienced drought stress at first, and when the field water level dropped to the lower limit at the beginning of growth stage, irrigation water was added with an automatic irrigation system until the upper water level limit was reached; the field surface water was then drained to the maximum water level at normal time after 5 days. For the FFTD treatments, rice experienced flooding stress at first, and irrigation water was immediately added to the upper water level limit at the beginning of growth stage; the field surface water was then drained until there was no surface water after 5 days, and when the field water level dropped to the lower limit at the beginning of growth stage, irrigation water was added until the maximum water level at normal time was reached. The water level management complying with the shallow and wetting irrigation requirement was conducted on other days of each stage.

2.4. Sample Collection and Measurement. Field water depth was observed at nine oclock by a ruler. When the minimum level was reached, the system would irrigate until water level reached maximum level. Similarly, when water level exceeded maximum because of rainfall, the drainage volume was subsequently calculated by counting the number of opened solenoid valves and stored by a data logger. Water samples were collected in polyethylene bottles for three times during the submergence period. The surface water was collected using $50 \mathrm{~mL}$ syringes (without disturbing the soil and selecting the top surface water randomly); all bottles were rinsed before appropriate amount of water sample was obtained. An underground drainage pipe was installed at the bottom of the tanks (the distance between underground outlet and field surface is $1.5 \mathrm{~m}$ ). The collection time of percolation water was in accordance with surface water. As there was no surface water in field, the percolation water was collected when the water level reached $0 \mathrm{~mm},-250 \mathrm{~mm}$, and $-500 \mathrm{~mm}$. Ammonia nitrogen $\left(\mathrm{NH}_{4}{ }^{+}-\mathrm{N}\right)$, nitrate nitrogen $\left(\mathrm{NO}_{3}{ }^{-} \mathrm{N}\right)$, and $\mathrm{TP}$ in the water samples were analyzed by the indophenol blue, disulfonic acid phenol, and ammonium molybdate methods using a UV-2800 spectrophotometer.

2.5. Statistical Analysis. A randomized complete block design with three replications was employed. Treatment effects were analyzed using SPSS software version 19.0. $t$-tests at $P \leq 0.05$ were used to calculate the difference of mean concentrations in surface water among different treatments. Significance was calculated based on least significant difference (LSD) test at $P \leq 0.05$, except when $t$-tests were used.

\section{Results}

3.1. Change of $\mathrm{NH}_{4}^{+}-\mathrm{N}$ Concentration. $\mathrm{NH}_{4}^{+}-\mathrm{N}$ concentrations over the study period are shown in Figure $1 . \mathrm{NH}_{4}{ }^{+}-\mathrm{N}$ concentrations reduced with the time of flooding in FFTD and FDTF surface water at each stage. Compared with the first day of flooding at each stage, the $\mathrm{NH}_{4}{ }^{+}-\mathrm{N}$ concentrations for the FFTD surface water were decreased by $50.9 \%, 42.2 \%$, $54.74 \%$, and $42.1 \%$ at the end of flooding; the $\mathrm{NH}_{4}{ }^{+}-\mathrm{N}$ concentrations for the FDTF surface water were decreased by $55.2 \%, 53.1 \%, 51.0 \%$, and $32.5 \%$. The mean $\mathrm{NH}_{4}{ }^{+}-\mathrm{N}$ concentrations in FFTD surface water were significantly higher than those in FDTF surface water at each stage (Table 2).

First, $\mathrm{NH}_{4}{ }^{+}-\mathrm{N}$ concentrations in the FFTD percolation water were reduced with time during the study period and then stabilized at each stage. The $\mathrm{NH}_{4}{ }^{+}-\mathrm{N}$ concentrations in FDTF percolation water reached the maximum on the first day of flooding at each stage. Moreover, the maximum of $\mathrm{NH}_{4}{ }^{+}-\mathrm{N}$ concentrations in FDTF percolation water was significantly higher than that at the water level of $-500 \mathrm{~mm}$. Compared with the first day of flooding at each stage, the $\mathrm{NH}_{4}{ }^{+}-\mathrm{N}$ concentrations for the FFTD percolation water were decreased by $22.9 \%, 49.8 \%, 65.7 \%$, and $21.1 \%$ at the end of flooding; the $\mathrm{NH}_{4}^{+}-\mathrm{N}$ concentrations for the FDTF percolation water were decreased by $37.4 \%, 55.6 \%, 61.8 \%$, and $36.3 \%$. During the time of flooding, the mean $\mathrm{NH}_{4}{ }^{+}-\mathrm{N}$ concentrations in FDTF percolation water were significantly higher than those in FFTD percolation water at each stage (Table 3). For the FFTD and FDTF treatments, the mean $\mathrm{NH}_{4}{ }^{+}-\mathrm{N}$ concentrations in percolation water under flooding condition were significantly higher than those under drought condition at each stage (Table 3).

3.2. Change of $\mathrm{NO}_{3}{ }^{-}-\mathrm{N}$ Concentration. The dynamics of change of $\mathrm{NO}_{3}{ }^{-}-\mathrm{N}$ concentrations in water at the four stages is shown in Figure 2. In addition to FDTF surface water at stage IV, the $\mathrm{NO}_{3}{ }^{-}-\mathrm{N}$ concentrations reduced with the time of flooding in surface water at each stage. In stage IV, the maximum of $\mathrm{NO}_{3}{ }^{-}-\mathrm{N}$ concentrations in FDTF surface 

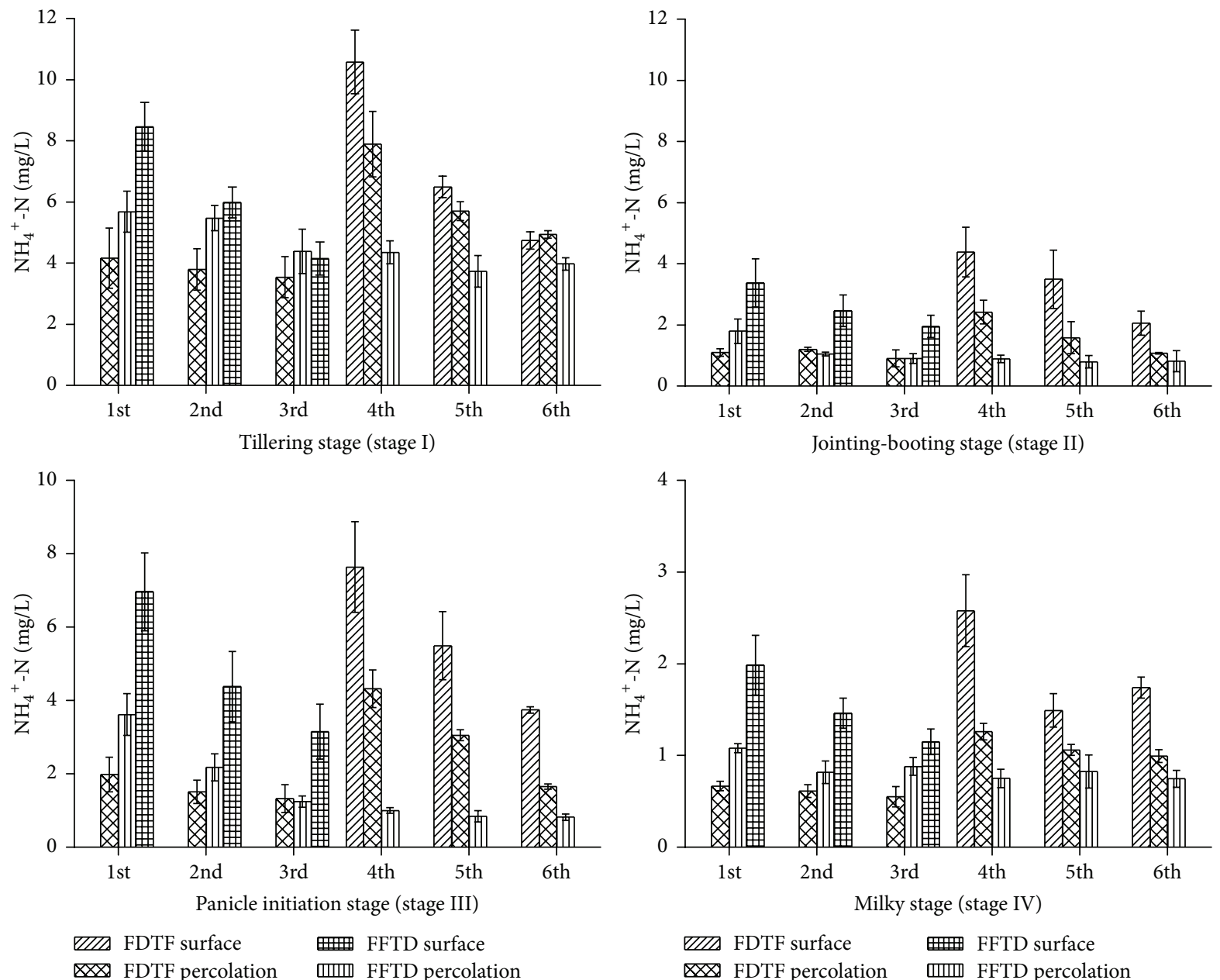

FIGURE 1: Change of $\mathrm{NH}_{4}{ }^{+}-\mathrm{N}$ concentration at each stage. FDTF indicates first drought and then flooding; FFTD indicates first flooding and then drought. 1st, 2nd, and 3rd indicate the concentration on the first, third, and fifth day of flooding for the FFTD treatments and at the water level of $0 \mathrm{~mm},-250 \mathrm{~mm}$, and $-500 \mathrm{~mm}$ for the FDTF treatments. 4th, 5th, and 6th indicate the concentration on the first, third, and fifth day of flooding for the FDTF treatments and at the water level of $0 \mathrm{~mm},-250 \mathrm{~mm}$, and $-500 \mathrm{~mm}$ for the FFTD treatments. Vertical bars represent standard error of the mean.

TABle 3: Mean TP, $\mathrm{NH}_{4}{ }^{+}-\mathrm{N}$, and $\mathrm{NO}_{3}{ }^{-}-\mathrm{N}$ concentrations in percolation water at different stages during the time of flooding and drought.

\begin{tabular}{|c|c|c|c|c|c|c|c|c|c|}
\hline \multirow{3}{*}{$\begin{array}{l}\text { Form of } \mathrm{N} \text { and } \mathrm{P} \\
\left(\mathrm{mg} \cdot \mathrm{L}^{-1}\right)\end{array}$} & \multirow{3}{*}{ Treatments } & \multicolumn{7}{|c|}{ Time } & \\
\hline & & \multicolumn{2}{|c|}{$\begin{array}{l}\text { Tillering stage (stage } \\
\text { I) }\end{array}$} & \multicolumn{2}{|c|}{$\begin{array}{l}\text { Jointing-booting stage } \\
\text { (stage II) }\end{array}$} & \multicolumn{2}{|c|}{$\begin{array}{l}\text { Panicle initiation } \\
\text { stage (stage III) }\end{array}$} & \multicolumn{2}{|c|}{ Milky stage (stage IV) } \\
\hline & & Flooding & Drought & Flooding & Drought & Flooding & Drought & Flooding & Drought \\
\hline \multirow{2}{*}{$\mathrm{NH}_{4}^{+}-\mathrm{N}$} & FFTD & $5.17^{\mathrm{b}}$ & $4.01^{\mathrm{c}}$ & $1.24^{\mathrm{b}}$ & $0.83^{\mathrm{c}}$ & $2.34^{\mathrm{b}}$ & $0.88^{\mathrm{d}}$ & $0.92^{\mathrm{b}}$ & $0.77^{\mathrm{c}}$ \\
\hline & FDTF & $6.18^{\mathrm{a}}$ & $3.83^{c}$ & $1.69^{\mathrm{a}}$ & $1.07^{\mathrm{c}}$ & $3.01^{\mathrm{a}}$ & $1.60^{c}$ & $1.10^{\mathrm{a}}$ & $0.61^{\mathrm{c}}$ \\
\hline \multirow{2}{*}{$\mathrm{NO}_{3}{ }^{-}-\mathrm{N}$} & FFTD & $1.72^{\mathrm{b}}$ & $1.17^{\mathrm{c}}$ & $0.83^{\mathrm{b}}$ & $0.39^{c}$ & $1.33^{\mathrm{b}}$ & $0.79^{c}$ & $0.51^{\mathrm{a}}$ & $0.34^{\mathrm{b}}$ \\
\hline & FDTF & $2.43^{\mathrm{a}}$ & $1.53^{\mathrm{c}}$ & $1.10^{\mathrm{a}}$ & $0.86^{\mathrm{b}}$ & $1.78^{\mathrm{a}}$ & $1.35^{\mathrm{b}}$ & $0.57^{\mathrm{a}}$ & $0.26^{\mathrm{b}}$ \\
\hline \multirow{2}{*}{$\mathrm{TP}$} & FFTD & $0.088^{b}$ & $0.056^{\mathrm{c}}$ & $0.055^{\mathrm{b}}$ & $0.038^{c}$ & $0.046^{\mathrm{b}}$ & $0.036^{\mathrm{c}}$ & $0.032^{\mathrm{a}}$ & $0.035^{\mathrm{a}}$ \\
\hline & FDTF & $0.106^{\mathrm{a}}$ & $0.066^{c}$ & $0.101^{\mathrm{a}}$ & $0.034^{\mathrm{c}}$ & $0.064^{\mathrm{a}}$ & $0.034^{\mathrm{c}}$ & $0.039^{\mathrm{a}}$ & $0.040^{\mathrm{a}}$ \\
\hline
\end{tabular}

Note: mean values in the same row followed by the same letter show nonsignificant difference. FDTF indicates first drought and then flooding; FFTD indicates first flooding and then drought. 

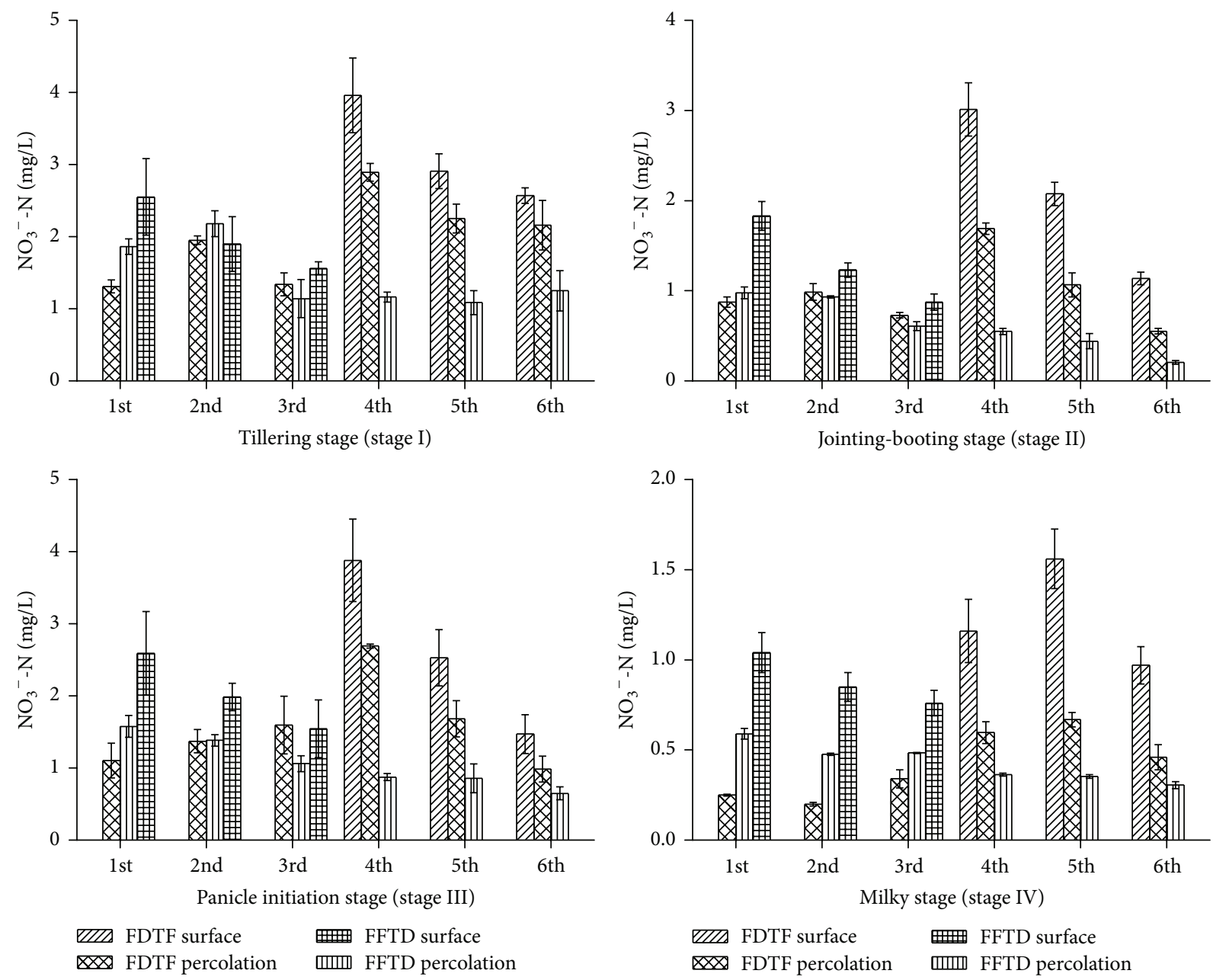

FIGURE 2: Change of $\mathrm{NO}_{3}{ }^{-}-\mathrm{N}$ concentration at each stage. FDTF indicates first drought and then flooding; FFTD indicates first flooding and then drought. 1st, 2nd, and 3rd indicate the concentration on the first, third, and fifth day of flooding for the FFTD treatments and at the water level of $0 \mathrm{~mm},-250 \mathrm{~mm}$, and $-500 \mathrm{~mm}$ for the FDTF treatments. 4th, 5th, and 6th indicate the concentration on the first, third, and fifth day of flooding for the FDTF treatments and at the water level of $0 \mathrm{~mm},-250 \mathrm{~mm}$, and $-500 \mathrm{~mm}$ for the FFTD treatments. Vertical bars represent standard error of the mean.

water was observed on the third day after flooding. Compared with the first day of flooding at each stage, the $\mathrm{NO}_{3}{ }^{-}-\mathrm{N}$ concentrations for the FFTD surface water were decreased by $35.1 \%, 62.2 \%, 62.1 \%$, and $16.4 \%$ at the end of flooding; the $\mathrm{NO}_{3}{ }^{-}-\mathrm{N}$ concentrations for the FDTF surface water were decreased by $38.8 \%, 52.2 \%, 40.4 \%$, and $26.9 \%$. The mean $\mathrm{NO}_{3}{ }^{-}$-N concentrations in FDTF surface water were significantly higher than those in FFTD surface water at each stage (Table 2).

The $\mathrm{NO}_{3}{ }^{-}-\mathrm{N}$ concentrations reached the peak value on the third day of flooding in FFTD percolation water at stage I. The $\mathrm{NO}_{3}{ }^{-}-\mathrm{N}$ concentrations showed a declining trend and then fluctuated slightly in FFTD percolation water during the growth stage, except at stage I. For the FDTF treatments, the $\mathrm{NO}_{3}{ }^{-}-\mathrm{N}$ concentrations in percolation water showed a rising trend at first and then a decrease at stage I; the $\mathrm{NO}_{3}{ }^{-}-\mathrm{N}$ concentrations fluctuated in other stages. Moreover, the $\mathrm{NO}_{3}{ }^{-}-\mathrm{N}$ concentrations on the first day of flooding in FDTF percolation water at each stage were significantly higher than that at the water level of $-500 \mathrm{~mm}$. Compared with the first day of flooding at each stage, the $\mathrm{NO}_{3}{ }^{-}-\mathrm{N}$ concentrations for the FFTD percolation water were decreased by $38.7 \%, 37.8 \%, 32.8 \%$, and $17.8 \%$ at the end of flooding; the $\mathrm{NO}_{3}{ }^{-}$-N concentrations for the FDTF percolation water were decreased by $25.3 \%, 67.4 \%, 63.4 \%$, and $23.0 \%$. During the time of flooding, the mean $\mathrm{NO}_{3}{ }^{-}-\mathrm{N}$ concentrations in FDTF percolation water were significantly higher than that in FFTD percolation water at each stage (Table 3 ). For the FFTD and FDTF treatments, the mean $\mathrm{NO}_{3}^{-}-\mathrm{N}$ concentrations in percolation water under flooding condition were significantly higher than that under drought condition during the growth stage, except at stage IV (Table 3).

3.3. The Change of TP Concentrations. The dynamics of change of TP concentrations in water at the four stages is shown in Figure 3. TP concentrations in FFTD and FDTF surface water reduced with the time of flooding at each stage. Compared with the first day of flooding at each stage, the TP 

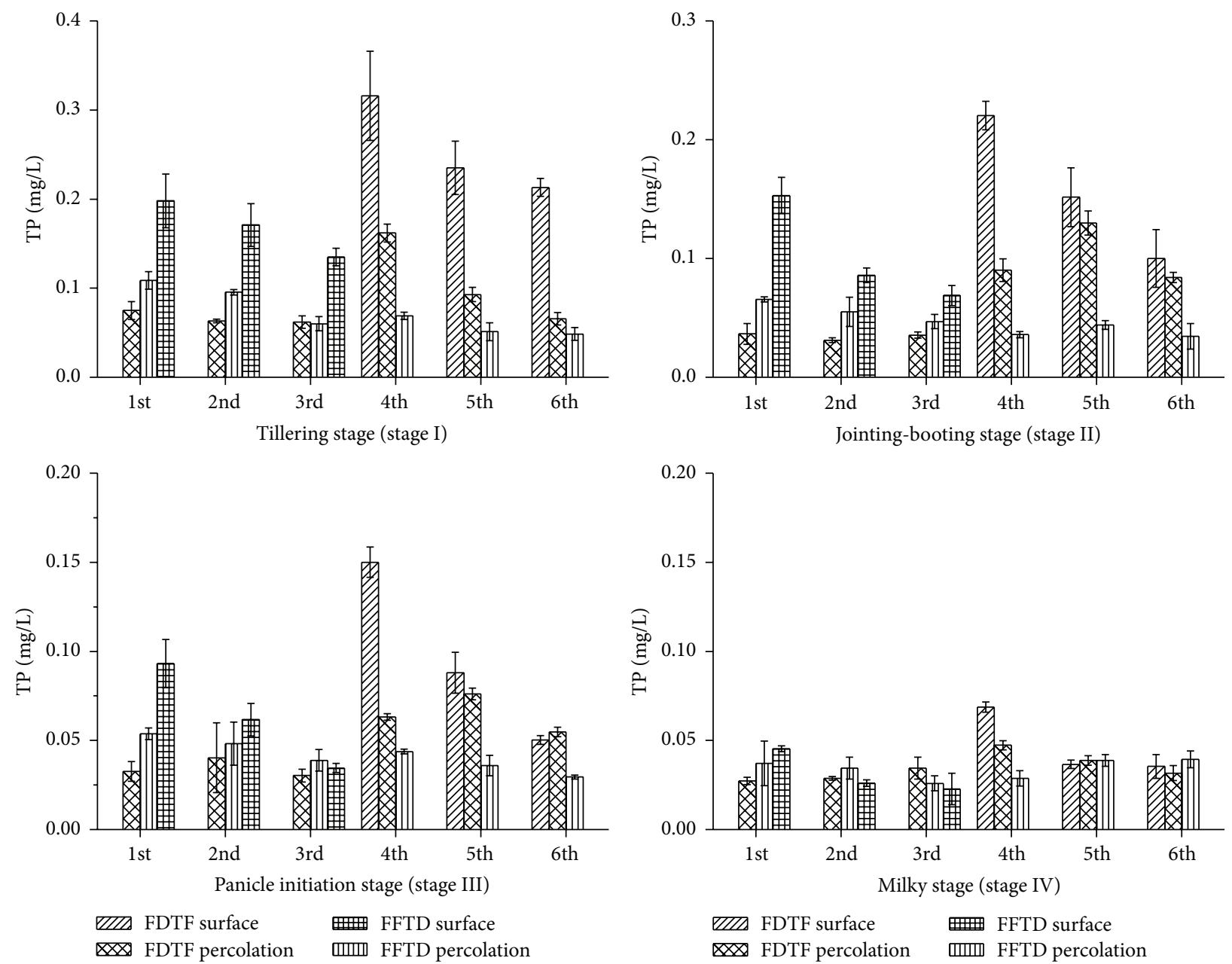

FIGURE 3: Change of TP concentration at each stage. FDTF indicates first drought and then flooding; FFTD indicates first flooding and then drought. 1st, 2nd, and 3rd indicate the concentration on the first, third, and fifth day of flooding for the FFTD treatments and at the water level of $0 \mathrm{~mm},-250 \mathrm{~mm}$, and $-500 \mathrm{~mm}$ for the FDTF treatments. $4 \mathrm{th}, 5 \mathrm{th}$, and 6 th indicate the concentration on the first, third, and fifth day of flooding for the FDTF treatments and at the water level of $0 \mathrm{~mm},-250 \mathrm{~mm}$, and $-500 \mathrm{~mm}$ for the FFTD treatments. Vertical bars represent standard error of the mean.

concentrations for the FFTD surface water were decreased by $31.8 \%, 55.0 \%, 62.9 \%$, and $49.9 \%$ at the end of flooding; the TP concentrations for the FDTF surface water were decreased by $32.6 \%, 54.6 \%, 66.5 \%$, and $48.4 \%$. The mean TP concentrations in FDTF surface water were significantly higher than those in FFTD surface water at each stage, except at stage IV (Table 2).

The TP concentrations fluctuated widely in percolation water at each stage. In FDTF percolation water, the TP concentrations reached the maximum on the third day of flooding and then declined at stages II and III. The TP concentrations in percolation water decreased with time in the other stages. Compared with the first day of flooding at each stage, the TP concentrations for the FFTD percolation water were decreased by $44.8 \%, 28.4 \%, 27.7 \%$, and $30.3 \%$ at the end of flooding; the TP concentrations for the FDTF percolation water were decreased by $59.4 \%, 6.7 \%, 13.3 \%$, and $33.2 \%$. During the time of flooding, the mean TP concentrations in FDTF percolation water were significantly higher than that in FFTD percolation water at each stage, except at stage
IV (Table 3). Moreover, mean TP concentrations in FDTF and FFTD percolation waters under flooding condition were significantly higher than that under drought condition at each stage, except at stage IV (Table 3 ).

\section{Discussion}

4.1. Impact of $\mathrm{CID}$ on $\mathrm{NH}_{4}^{+}-\mathrm{N}$ and $\mathrm{NO}_{3}{ }^{-}-\mathrm{N}$ Concentrations in Surface Water. The $\mathrm{NH}_{4}{ }^{+}-\mathrm{N}$ and $\mathrm{NO}_{3}{ }^{-}-\mathrm{N}$ concentrations were clearly affected by the duration of flooding (Figures 1 and 2). $\mathrm{NH}_{4}{ }^{+}-\mathrm{N}$ and $\mathrm{NO}_{3}{ }^{-}-\mathrm{N}$ concentrations change continuously according to biochemical reactions involved, and the rates of these reactions correlate with the water depth [22]. With the microbial interactions, soil particles sedimentation, and plant uptake, implementation of CID can significantly decrease $\mathrm{NH}_{4}{ }^{+}-\mathrm{N}$ and $\mathrm{NO}_{3}{ }^{-}-\mathrm{N}$ concentrations in surface water in this study. Shao et al. reported that CID could decrease water flow [23]. Thus, the decrease in losses of $\mathrm{NH}_{4}{ }^{+}-\mathrm{N}$ and $\mathrm{NO}_{3}{ }^{-}-\mathrm{N}$ by CID implementation is not only 
associated with runoff volume but also related to $\mathrm{NH}_{4}{ }^{+}-\mathrm{N}$ and $\mathrm{NO}_{3}{ }^{-}-\mathrm{N}$ concentrations. During prolonged flooding, biological denitrification is strengthened and nitrification is suppressed in low-oxygen environments [24]. $\mathrm{NH}_{4}{ }^{+}-\mathrm{N}$ is the stable component of $\mathrm{N}$ in paddy water $[1,7]$, and thus $\mathrm{NH}_{4}{ }^{+}-\mathrm{N}$ is the dominant form of $\mathrm{N}$ runoff. Similar results were also found in paddy soil in Southern China $[5,25]$. Low water availability can inhibit microbial activity by lowering intracellular water potential and reducing hydration and activity of enzymes in soil [26], resulting in the accumulation of inorganic $\mathrm{N}$ under drought conditions. Meanwhile, reflooding a dry soil promotes $\mathrm{N}$ mineralization [27]. The amount of $\mathrm{N}$ tied up in bacterial osmolytes may be metabolized on reflooding, initially producing a pulse of dissolved organic $\mathrm{N}$ that may then be mineralized and nitrified [28]. Therefore, CID may be a useful strategy to control $\mathrm{N}$ runoff when paddy fields are flooded after drought. Careful consideration must be given to the $\mathrm{NH}_{4}{ }^{+}-\mathrm{N}$ and $\mathrm{NO}_{3}{ }^{-} \mathrm{N}$ runoff concentration when water stress transforms from drought to flooding.

4.2. Impact of $\mathrm{CID}$ on $\mathrm{NH}_{4}{ }^{+}-\mathrm{N}$ and $\mathrm{NO}_{3}{ }^{-}-\mathrm{N}$ Concentrations in Percolation Water. N leaching may be affected by soil properties, water management, and crop growth. Surface subsidence and cracks formed in soil because of drought influence soil structure and quality. Water is quickly percolated when the soil is reflooded after drought, and nutrients through the cracks preferentially migrate into the subsoil $[29,30]$. As a result, flooding can sharply increase the $\mathrm{NH}_{4}{ }^{+}-\mathrm{N}$ and $\mathrm{NO}_{3}{ }^{-}-\mathrm{N}$ concentrations in leachates after drought. Moreover, the mean $\mathrm{NH}_{4}{ }^{+}-\mathrm{N}$ and $\mathrm{NO}_{3}{ }^{-}-\mathrm{N}$ concentrations were significantly higher in percolation water under flooding stress than those under drought stress during the growth stage. In general, $\mathrm{NO}_{3}{ }^{-}-\mathrm{N}$ leaching is more likely to occur than $\mathrm{NH}_{4}{ }^{+}-\mathrm{N}$ leaching because of soil adsorption of $\mathrm{NH}_{4}{ }^{+}-\mathrm{N}$ and the migration distance of $\mathrm{NH}_{4}{ }^{+}-\mathrm{N}$ in soil is very short $[18,31,32]$. However, the current study found significantly higher $\mathrm{NH}_{4}{ }^{+}-\mathrm{N}$ than $\mathrm{NO}_{3}{ }^{-}-\mathrm{N}$ concentrations in percolation water. This finding may be due to long-term flooding, confined process of nitrification, and intense denitrification. In addition, the soil was maintained in a reduced state because of the outlet below shallow groundwater table in the experimental field during the time of drought [10], resulting in lack of oxygen. Moreover, a majority of $\mathrm{NH}_{4}{ }^{+}-\mathrm{N}$ in the percolation water from paddy fields also may come from the slow mineralization and decomposition of organic $\mathrm{N}$ in the subsoil [18].

4.3. Impact of CID on TP Concentrations. The mobility and transfer of $\mathrm{P}$ in paddy soil-water can be affected by flooding, resulting in changes of $\mathrm{P}$ concentrations in the field surface water. Moreover, the particles in topsoil are disturbed by irrigation, thereby inducing release and suspension of $\mathrm{P}$. In this experiment, we observed that $\mathrm{TP}$ concentrations in surface water followed a decreasing trend during the time of flooding, which was consistent with the research of Zhang et al. [33]. In addition, the mean TP concentrations in FDTF surface water were significantly higher than that in FDTF (Table 2), because the environment of FDTF has obviously improved the effectiveness of soil $\mathrm{P}$ and promoted the transformation of insoluble P into available P [34].

Soils generally have a strong adsorption capacity of $\mathrm{P}$ in paddy fields [35], and thus $P$ leaching can be ignored [36]. However, several studies have reported that $\mathrm{P}$ leaching is a main reason for water eutrophication $[10,18]$. Water is the medium of $\mathrm{P}$ leaching, which is closely related to field water table management in paddy soil. Certain amount of $\mathrm{P}$ in percolation water directly comes from downward migration of $\mathrm{P}$ in surface water and is positively correlated with $\mathrm{P}$ concentrations in surface water. Changes in $\mathrm{P}$ concentrations are often attributed to high water tables resulting from flooding, which promotes anaerobic conditions. Anaerobic soil conditions can increase the solubility and mobility of P [13]. Moreover, anaerobic conditions created by flooding water may increase the release of $\mathrm{P}$ to the soil solution because of the reduction of $\mathrm{Fe}^{3+}$ to $\mathrm{Fe}^{2+}$ [37]. As a result, the mean TP concentrations were significantly higher in percolation water under flooding stress than under drought stress during the growth stage, except at stage IV. Similar results in paddy soil in Southern China were also reported [38]. In early period of flooding after drought, high TP concentrations favor eutrophication because of the presence of cracks in the soil, thereby allowing TP to leach more easily through preferential flow. For paddy fields flooded after drought, soils become reduced because of the decrease in oxygen, and TP concentrations are increased continuously in the early period of flooding. As a result, P solubility and extractability in FDTF condition were relatively higher than those in FFTD, thereby increasing the risk of TP leaching.

\section{Conclusions}

Field experiments conducted in Southern China indicated that CID implementation increased the $\mathrm{N}$ and $\mathrm{P}$ use efficiencies via the reduction of $\mathrm{N}$ and $\mathrm{P}$ concentrations in surface and percolation water. $\mathrm{NH}_{4}{ }^{+}-\mathrm{N}$ and $\mathrm{NO}_{3}{ }^{-}-\mathrm{N}$ concentrations decreased with the duration of flooding in the four stages but differed considerably among the treatments. $\mathrm{NH}_{4}{ }^{+}-\mathrm{N}$ was the major form of $\mathrm{N}$ in surface drainage and percolation water. The TP concentration in surface water followed a decreasing trend during the time of flooding. Compared with FFTD, the mean $\mathrm{NH}_{4}{ }^{+}-\mathrm{N}, \mathrm{NO}_{3}{ }^{-}-\mathrm{N}$, and TP concentrations were significantly higher in FDTF surface water at each stage. Moreover, the mean $\mathrm{NH}_{4}{ }^{+}-\mathrm{N}, \mathrm{NO}_{3}{ }^{-}-\mathrm{N}$, and $\mathrm{TP}$ concentrations were significantly higher in percolation water under flooding stress than those under drought stress during the growth stage, except for the mean TP concentration at stage IV. Flooding after drought can sharply increase the $\mathrm{NH}_{4}{ }^{+}-\mathrm{N}_{1} \mathrm{NO}_{3}{ }^{-}-\mathrm{N}$, and TP concentrations in leachates. High $\mathrm{NH}_{4}{ }^{+}-\mathrm{N}, \mathrm{NO}_{3}{ }^{-}-\mathrm{N}$, and $\mathrm{TP}$ concentrations via runoff and leaching were an important cause of water eutrophication in paddy fields during the rice growing season. Thus, CID should be implemented to control the high concentrations of $\mathrm{NH}_{4}{ }^{+}-\mathrm{N}, \mathrm{NO}_{3}{ }^{-}-\mathrm{N}$, and TP when water stress transforms from drought to flooding. 
Abbreviations

$\begin{array}{ll}\text { CID: } & \text { Controlled irrigation and drainage } \\ \text { CD: } & \text { Controlled drainage } \\ \text { AWD: } & \text { Alternate wetting and drying } \\ \text { FDTF: } & \text { First drought and then flooding } \\ \text { FFTD: } & \text { First flooding and then drought } \\ \mathrm{N}: & \text { Nitrogen } \\ \mathrm{P}: & \text { Phosphorus } \\ \mathrm{NH}_{4}{ }^{+}-\mathrm{N}: & \text { Ammonium nitrogen } \\ \mathrm{NO}_{3}{ }^{-}-\mathrm{N}: & \text { Nitrate nitrogen } \\ \mathrm{TP}^{-} & \text {Total phosphorus } \\ \text { Stage I: } & \text { Tillering stage } \\ \text { Stage II: } & \text { Jointing and booting stage } \\ \text { Stage III: } & \text { Heading and flowering stage } \\ \text { Stage IV: } & \text { Milky stage. }\end{array}$

\section{Competing Interests}

The authors declare that there are no competing interests regarding the publication of this paper.

\section{Acknowledgments}

This work was funded by the Key Program granted by the National Nature \& Science Foundation of China (nos. 51479063 and 41401628) and supported by the Fundamental Research Funds for the Central Universities (nos. 2015B34614 and 2015B14714) and the Priority Academic Program Development of Jiangsu Higher Education Institutions.

\section{References}

[1] M.-H. Xiao, S.-E. Yu, D. She, X.-J. Hu, and L.-L. Chu, "Nitrogen and phosphorus loss and optimal drainage time of paddy field under controlled drainage condition," Arabian Journal of Geosciences, vol. 8, no. 7, pp. 4411-4420, 2015.

[2] H. J. Sun, H. L. Zhang, Z. M. Yu et al., "Combination system of full-scale constructed wetlands and wetland paddy fields to remove nitrogen and phosphorus from rural unregulated nonpoint sources," Environmental Geochemistry and Health, vol. 35, no. 6, pp. 801-809, 2013.

[3] H. Nakasone, M. A. Abbas, and H. Kuroda, "Nitrogen transport and transformation in packed soil columns from paddy fields," Paddy and Water Environment, vol. 2, no. 3, pp. 115-124, 2004.

[4] L. Van Chinh, K. Hiramatsu, M. Harada, and M. Mori, "Nitrogen and phosphorus runoff modeling in a flat low-lying paddy cultivated area," Paddy and Water Environment, vol. 6, no. 4, pp. 405-414, 2008.

[5] X. Hu, X. Shao, Y. Li, J. He, S. Lu, and Y. Qiu, "Effects of controlled and mid-gathering irrigation mode of paddy rice on the pollutants emission and reduction," Energy Procedia, vol. 16, pp. 907-914, 2012.

[6] M.-H. Xiao, S.-E. Yu, G. Cheng, and D.-L. Shao, "Technical standards of irrigation and drainage management in paddy field of water-saving and pollution-reduction with high yield," Journal of Food, Agriculture and Environment, vol. 10, no. 2, pp. 1005-1011, 2012.
[7] X. Zhao, Y. Zhou, J. Min, S. Q. Wang, W. M. Shi, and G. X. Xing, "Nitrogen runoff dominates water nitrogen pollution from ricewheat rotation in the Taihu Lake region of China," Agriculture, Ecosystems \& Environment, vol. 156, pp. 1-11, 2012.

[8] J. Z. Xu, S. Z. Peng, S. H. Yang, and W. G. Wang, "Ammonia volatilization losses from a rice paddy with different irrigation and nitrogen managements," Agricultural Water Management, vol. 104, pp. 184-192, 2012.

[9] R. Kröger, S. C. Pierce, K. A. Littlejohn, M. T. Moore, and J. L. Farris, "Decreasing nitrate-N loads to coastal ecosystems with innovative drainage management strategies in agricultural landscapes: an experimental approach," Agricultural Water Management, vol. 103, pp. 162-166, 2012.

[10] J. Wang, D. J. Wang, G. Zhang et al., "Nitrogen and phosphorus leaching losses from intensively managed paddy fields with straw retention," Agricultural Water Management, vol. 141, pp. 66-73, 2014.

[11] R. O. Evans, R. W. Skaggs, and J. W. Giiliam, "Controlled versus conventional drainage effects on water quality," Journal of Irrigation and Drainage Engineering, vol. 121, no. 4, pp. 271276, 1995.

[12] B. Bohne, I. J. Storchenegger, and P. Widmoser, "An easy to use calculation method for weir operations in controlled drainage systems," Agricultural Water Management, vol. 109, pp. 46-53, 2012.

[13] M. R. Williams, K. W. King, and N. R. Fausey, "Drainage water management effects on tile discharge and water quality," Agricultural Water Management, vol. 148, pp. 43-51, 2015.

[14] G. Bonaiti and M. Borin, "Efficiency of controlled drainage and subirrigation in reducing nitrogen losses from agricultural fields," Agricultural Water Management, vol. 98, no. 2, pp. 343352, 2010.

[15] M. D. Dukes, R. O. Evans, J. W. Gilliam, and S. H. Kunickis, "Interactive effects of controlled drainage and riparian buffers on shallow groundwater quality," Journal of Irrigation and Drainage Engineering, vol. 129, no. 2, pp. 82-92, 2003.

[16] I. Wesström, I. Messing, H. Linnér, and J. Lindström, "Controlled drainage-effects on drain outflow and water quality," Agricultural Water Management, vol. 47, no. 2, pp. 85-100, 2001.

[17] B. A. M. Bouman, L. Feng, T. P. Tuong, G. Lu, H. Wang, and Y. Feng, "Exploring options to grow rice using less water in northern China using a modelling approach. II. Quantifying yield, water balance components, and water productivity," Agricultural Water Management, vol. 88, no. 1-3, pp. 23-33, 2007.

[18] S.-Z. Peng, S.-H. Yang, J.-Z. Xu, Y.-F. Luo, and H.-J. Hou, "Nitrogen and phosphorus leaching losses from paddy fields with different water and nitrogen managements," Paddy and Water Environment, vol. 9, no. 3, pp. 333-342, 2011.

[19] X. Z. Tan, D. G. Shao, H. H. Liu, F. S. Yang, C. Xiao, and H. D. Yang, "Effects of alternate wetting and drying irrigation on percolation and nitrogen leaching in paddy fields," Paddy and Water Environment, vol. 11, no. 1-4, pp. 381-395, 2013.

[20] N. Pirmoradian, A. R. Sepaskhah, and M. Maftoun, "Effects of water-saving irrigation and nitrogen fertilization on yield and yield components of rice (Oryza sativa L.)," Plant Production Science, vol. 7, no. 3, pp. 337-346, 2004.

[21] G. Shao, J. Cui, S. Yu et al., "Impacts of controlled irrigation and drainage on the yield and physiological attributes of rice," Agricultural Water Management, vol. 149, pp. 156-165, 2015.

[22] I. Yoshinaga, A. Miura, T. Hitomi, K. Hamada, and E. Shiratani, "Runoff nitrogen from a large sized paddy field during a crop 
period," Agricultural Water Management, vol. 87, no. 2, pp. 217222, 2007

[23] G.-C. Shao, S. Deng, N. Liu, S.-E. Yu, M.-H. Wang, and D.-L. She, "Effects of controlled irrigation and drainage on growth, grain yield and water use in paddy rice," European Journal of Agronomy, vol. 53, pp. 1-9, 2014.

[24] A. A. Elmi, C. Madramootoo, and C. Hamel, "Influence of water table and nitrogen management on residual soil $\mathrm{NO}_{3}^{-}$and denitrification rate under corn production in sandy loam soil in Quebec," Agriculture, Ecosystems \& Environment, vol. 79, no. 2-3, pp. 187-197, 2000.

[25] G.-C. Shao, M.-H. Wang, S.-E. Yu, N. Liu, M.-H. Xiao, and M. Yuan, "Potential of controlled irrigation and drainage for reducing nitrogen emission from rice paddies in Southern China," Journal of Chemistry, vol. 2015, Article ID 913470, 9 pages, 2015.

[26] J. M. Stark and M. K. Firestone, "Mechanisms for soil moisture effects on activity of nitrifying bacteria," Applied and Environmental Microbiology, vol. 61, no. 1, pp. 218-221, 1995.

[27] R. Seneviratne and A. Wild, "Effect of mild drying on the mineralization of soil nitrogen," Plant and Soil, vol. 84, no. 2, pp. 175-179, 1985.

[28] S.-R. Xiang, A. Doyle, P. A. Holden, and J. P. Schimel, "Drying and rewetting effects on $\mathrm{C}$ and $\mathrm{N}$ mineralization and microbial activity in surface and subsurface California grassland soils," Soil Biology and Biochemistry, vol. 40, no. 9, pp. 2281-2289, 2008.

[29] G. Crescimanno and G. Provenzano, "Soil shrinkage characteristic curve in clay soils: measurement and prediction," Soil Science Society of America Journal, vol. 63, no. 1, pp. 25-32, 1999.

[30] T. Sander and H. H. Gerke, "Preferential flow patterns in paddy fields using a dye tracer," Vadose Zone Journal, vol. 6, no. 1, pp. 105-115, 2007.

[31] Y.-H. Tian, B. Yin, L.-Z. Yang, S.-X. Yin, and Z.-L. Zhu, "Nitrogen runoff and leaching Losses during rice-wheat Rotations in Taihu Lake region, China ${ }^{\star}$, Pedosphere, vol. 17, no. 4, pp. 445456, 2007.

[32] V. Aparicio, J. L. Costa, and M. Zamora, "Nitrate leaching assessment in a long-term experiment under supplementary irrigation in humid Argentina," Agricultural Water Management, vol. 95, no. 12, pp. 1361-1372, 2008.

[33] Z. J. Zhang, J. Y. Zhang, R. He, Z. D. Wang, and Y. M. Zhu, "Phosphorus interception in floodwater of paddy field during the rice-growing season in TaiHu Lake Basin," Environmental Pollution, vol. 145, no. 2, pp. 425-433, 2007.

[34] S. K. Sanyal and S. K. De Datta, "Chemistry of phosphorus transformations in soil," in Advances in Soil Science, vol. 16, pp. 1-120, Springer, 1991.

[35] X. J. Xie, W. Ran, Q. R. Shen, C. Y. Yang, J. J. Yang, and Z. H. Cao, "Field studies on 32P movement and P leaching from flooded paddy soils in the region of Taihu Lake, China," Environmental Geochemistry and Health, vol. 26, no. 2, pp. 237-243, 2004.

[36] A. N. Sharpley, R. W. Mcdowell, and P. J. A. Kleinman, "Phosphorus loss from land to water: integrating agricultural and environmental management," Plant and Soil, vol. 237, no. 2, pp. 287-307, 2001.

[37] I. Wesström and I. Messing, "Effects of controlled drainage on $\mathrm{N}$ and $\mathrm{P}$ losses and $\mathrm{N}$ dynamics in a loamy sand with spring crops," Agricultural Water Management, vol. 87, no. 3, pp. 229240, 2007.

[38] Y.-H. Shan, L.-Z. Yang, T.-M. Yan, and J.-G. Wang, "Downward movement of phosphorus in paddy soil installed in large-scale monolith lysimeters," Agriculture, Ecosystems \& Environment, vol. 111, no. 1-4, pp. 270-278, 2005. 

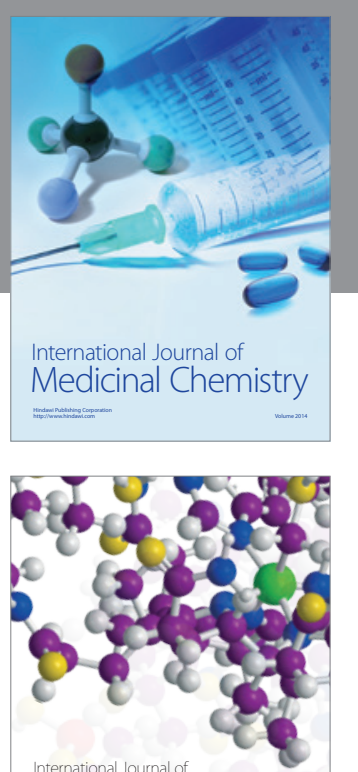

Carbohydrate Chemistry

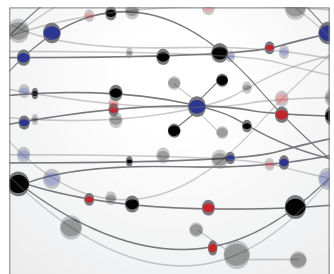

The Scientific World Journal
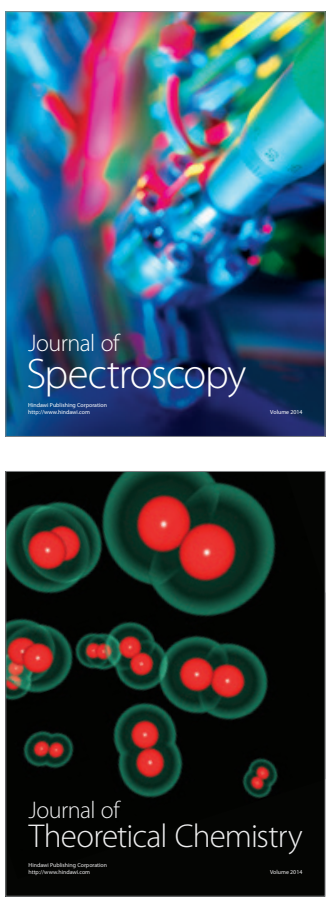


Submit your manuscripts at

http://www.hindawi.com

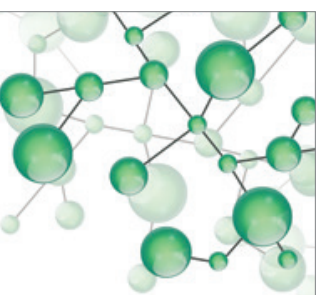

International Journal of

Inorganic Chemistry

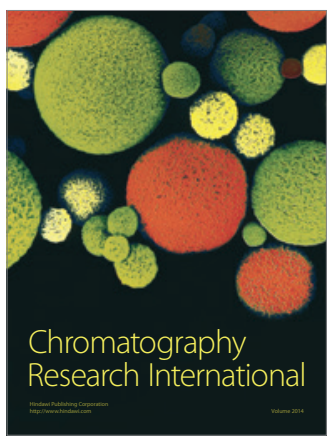

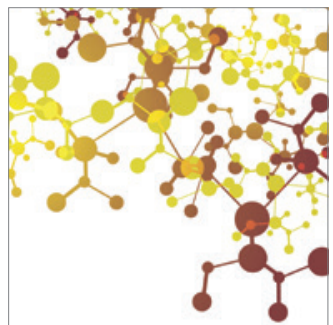

Applied Chemistry
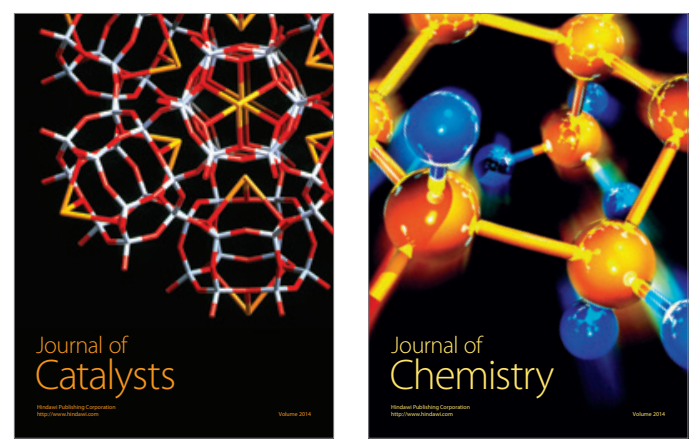
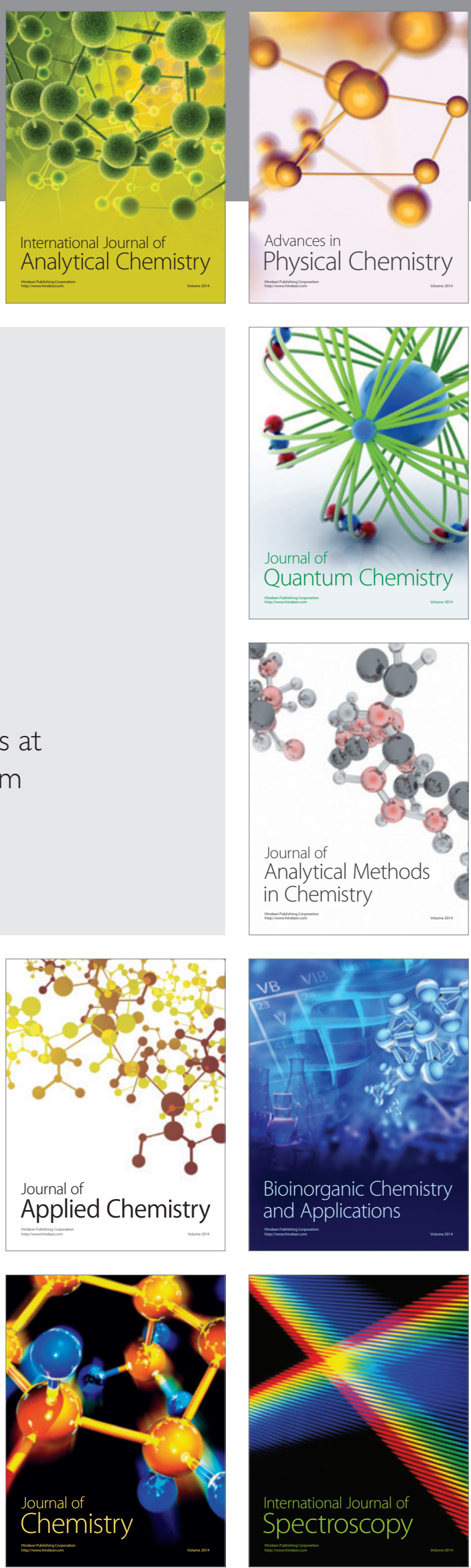